\title{
Teacher Preparation and Diversity: When American Pre-service Teachers Aren't White and Middle Class
}

\author{
Jodene Morrell \\ California State Polytechnic University Pomona
}

U.S. A.

The majority of American educators are White, middle class, and female. Most textbooks and articles for pre-service teachers assume their readers reflect these characteristics. However, as the K-12 student population becomes increasingly diverse, so do the pre-service teacher candidates at our Southern California public university. This article describes a prerequisite education course on diversity, showing how its original assumption that students needed to be convinced of the importance of diversity changed to a focus on improving the academic achievement and opportunities for linguistically and culturally diverse K-12 students.

Education in a Diverse Society

Transforming the Course

Theories and Theorists: Making Sense of Their Own Education

Revising Core Projects to Meet Expected Outcomes

Refining the Course

Conclusion

References

The United States is incredibly diverse, as reflected by our K-12 student population; however, we continue to experience a shortage of minority teachers (Sims, 2010). California, with the largest state population (U.S. Census Bureau, 2009) and the second largest school district in the country, educates $72.1 \%$ nonWhite students, but the teacher population remains close to the national average at approximately $70 \%$ White (Ed-Data, 2008). Given these statistics, it is not surprising that teacher education scholarship addresses the increasing diversity among K-12 students but gives little attention to non-White pre-service teachers. As we continue to analyze and tailor curriculum and pedagogy to meet the needs of elementary and secondary students, we should do the same for teacher education programs so that they respond to the experiences and knowledge all of our students bring to the university classroom, particularly pre-service teachers who do not reflect state and national averages in demographics or views about diversity. Recently, this issue was brought to my attention as an instructor for one 
of our credential courses, Education in a Diverse Society, a prerequisite for students earning a Multiple Subjects (K-8), Single Subject (Secondary), or Education Specialist (mild to severe special education) teaching credential at our large public institution in Southern California.

Requiring students to take a diversity course is intended to prepare them for a rapidly changing $\mathrm{K}-12$ student population and is common among teacher preparation programs. Theoretically, helping pre-service teachers address their possible biases and recognize and appreciate their future students' multicultural backgrounds will foster K-12 students' academic achievement (Bank, 2008; Grant \& Sleeter, 2007; Pewewardy, 2005). Sleeter (2001) asserts that preservice programs need to "try to develop the attitudes and multicultural knowledge base of predominantly White cohorts of pre-service students" (p. 96). In her review of studies on the preparation of teachers for historically underserved, multicultural student populations, Sleeter found that, as a whole, White students brought little cross-cultural background knowledge and experience to the classroom. They also held negative stereotypical beliefs about urban children, lacked awareness or understanding of discrimination and racism, and "used colorblindness as a way of coping with fear and ignorance" (p. 95).

As previously stated, while the majority of American teachers continue to be White, middle class and female, this is not the case for the 49.8 million K-12 public school students. In 2007, 56\% were White and $44 \%$ were non-White, with African Americans (15.3\%) and Hispanics/Latinos (20.9\%) representing the largest groups. Since 1972, the number of non-White students has increased while the number of White students has consistently decreased (National Center for Educational Statistics, 2009). While this may not be the case for most university campuses, this change in demographics is reflected on my campus, which has experienced significant growth among non-White student groups, particularly Hispanic/Latinos (20\%) and Asian/Pacific Islanders (23\%). Our students often labeled "White" $(24.7 \%)$ have attended diverse K-12 schools and colleges in nearby communities (California State University Statistical Abstract, 2007) and many bring a desire to learn and teach in diverse contexts (Wiseman, Knight, \& Cooner, 2005, p. 16). Recognizing the rich experiences and knowledge of our students has raised important and timely questions about how to transform and improve our diversity course to meet our students' needs.

\section{Education in a Diverse Society}

To apply to our credential program, students must complete the Education in a Diverse Society course. In 2006, I became the course coordinator and a faculty instructor. Our university catalog describes the course content as follows: "Explores the nature of culture as a complex body of knowledge related to the understanding of self, others and schooling. Explores diversity in relation to educational history, philosophy, sociology and law which forms a basis for equity, ethics and understanding." The catalog description is broad, but instructors must 
incorporate readings, assignments, and class discussions to address expected outcomes approved by the California Commission on Teacher Credentialing (CCTC). These expected outcomes include analyzing culture, ethnic and cultural identity, gender equity, English learners and language programs, assessment for English learners, and current laws related to parents, teachers, and students. While some assignments and core texts have varied over the past decade, the general focus and assumptions about the purpose of the course and the beliefs and knowledge about our students have not. The fact that our students do not reflect the national teaching population by ethnicity and class requires reconsideration of our curriculum and assumptions about how to prepare our students. Therefore, in this article I address challenges related to curricular transformations, discussions around and within the course, and assumptions about our students' experiences and knowledge.

Over the past few decades, California has experienced consistent and significant shifts in K-12 student demographics (National Center for Educational Statistics, 2009). One of the fastest growing groups in Southern California is Hispanics/Latinos. In 1987, they represented $28 \%$ of the school-age population and grew to $49 \%$ in 2008. During the 2006 - 2007 academic year, California provided English Learner services to 1.5 million students (State of California Education Profile, 2006-2007). Close to our university is the second largest school district in the country, the Los Angeles Unified School District, which educated many of our undergraduate students and hires our credential students. Nearly $32 \%$ of its students are in English Learner programs, and $63 \%$ of the students identified as Hispanic/Latino (Ed Data, District Profile, Los Angeles Unified School District, 2008-2009). Surrounding districts also reflect an increased enrollment of English Learners. Since the majority of our undergraduate students come from California, typically from nearby districts, they reflect the shifting demographics of the $\mathrm{K}-12$ school population as primarily bilingual and Hispanic/Latino. Not surprising, California preparation programs place a greater emphasis on language diversity than most states (Jennings, 2007).

Similar to other California state universities, we have experienced an increase in the percentage of non-White students and a steady decrease in the percentage of White students. In fact, we serve nearly $70 \%$ non-White students from freshmen to the graduate level (California State University Statistical Reports, 2007 - 2008), and the majority of our students in the credential program come from our undergraduate programs.

Fortunately, as Sleeter (2001) states, "Pre-service students of color tend to bring a richer multicultural knowledge base to teacher education than White students, and more commitment to multicultural teaching, social justice, and providing children of color with an academically challenging curriculum" (p. 95). Indeed, many of our students bring valuable experiences and knowledge from their K-12 education as English learners in diverse schools. Many students identify more closely with the diverse K-12 students than with the assumed White, middle class pre-service credential student discussed in books intended 
for pre-service teacher candidates. Our White, middle class students also tend to appreciate diversity and do not reflect views and biases of the White students often written about in deficit language in teacher preparation texts. Many of our credential students' experiences, knowledge, and perspectives challenge the curriculum intended for diversity courses. As in K-12 classrooms, our goal is to draw upon and build on our students' experiences and knowledge to increase their pedagogical content knowledge to best serve them and their future students. To move toward this goal requires a close examination of our diversity course and our students.

\section{Transforming the Course}

When I began teaching the course in 2005 , I drew on previous syllabi to address the expected outcomes approved by the CTCC. I had recently completed my doctoral program in Michigan, which influenced my assumptions about the California credential students, despite having taught elementary school in California for many years and being a student in California public schools from kindergarten through college.

Unlike many students in California, the pre-service teachers in Michigan did reflect the national characteristics of novice teachers: predominantly White, middle class, and female. After one year of teaching a course for multiple subjects (K-8) teacher candidates in a large public teacher education program, I only had four males and three non-White students out of approximately 80 students. When I discussed my eight years of teaching in large urban K-6 schools in California, several students informed me that they did not need to know about English learners, diversity, or urban education because it did not pertain to them or their future students. When I returned to California and began teaching the diversity course, I assumed the greatest challenge would be convincing students that diversity was important to consider and that their K-12 students might not share their home languages, cultural practices, and socioeconomic backgrounds. However, the majority of my students in California already understood and embodied these beliefs. I quickly discovered that the syllabi from previous courses did not accurately reflect students' a priori perspectives and experiences.

The California students' perspectives reflected what Jennings (2007) found in his study of diversity topics in teacher preparation programs across the United States. Jennings states that most educators have reached a consensus that addressing racial/ethnic diversity is the highest priority, so "the next step is to move beyond simply tolerating diversity and group differences and toward teaching for social change and the transformation of structural oppression in schools" (p. 1265). Our challenge as a faculty was to move beyond the assumption that we needed to convince our students that appreciating diversity is important and to show them how diversity can impact K-12 classrooms and educational opportunities for their students. Essentially, we needed to focus more 
on social justice and issues of equity and access to help our students move forward as reflective educators in diverse classrooms similar to the ones they experienced as $\mathrm{K}-12$ students.

\section{Curricular Changes over Time}

The core texts used in the course were considered timely, appropriate for diversity courses, and written by respected scholars. Many assumed that preservice teachers and the instructors were White; however, our instructors, who identify themselves as Latino/a, African American, Asian American, and multiethnic, outnumber our White instructors. Similarly, non-White students outnumber White students. Therefore assumptions found in many texts do not necessarily apply to our instructors and students.

Many texts used in the past focused heavily on topics or themes within multiculturalism and diversity. Granted, many have changed and new editions are available but I refer to those used when the courses were taught. Some divide multiculturalism into categories such as culture, equality, class, ethnicity and race, gender, exceptionality, religion, and language (e.g., Gollnick \& Chinn, 2002); concentrate on culture, racism, stereotypes, immigration, and learning styles (e.g., Noel, 2000); focus heavily on definitions and variations of culture such as immigrant, dominant, monoculturalism, biculturalism, and cultural frames of reference (e.g., Spring, 1999); or allocate a significant portion to issues of assimilation and pluralism and compare and contrast ethnic and cultural groups (e.g., Bennett, 2003). Instructors with a strong knowledge of linguistic diversity tended to use texts focused on primary and secondary language acquisition, English learners, and language programs (e.g., Crawford, 2004; Ovando, Combs \& Collier, 2002; Spangenberg-Urbschat \& Pritchard, 1994).

When I first taught the course (summer 2005), I selected two books, Intersections of Culture (Spring, 1999) and The Light in their Eyes: Creating Multicultural Learning Communities (Nieto, 1999) and supplemented these readings with articles and chapters. Several students asserted that the books were not adding to their existing knowledge of cultural diversity. In a weekly written response to the reading, a student named Nancy (pseudonym) wrote,

Not everyone receives the same public school education. We already knew this. Inequality exists in facilities, equipment, programming, tracking, curriculum and standardized testing. Most schools are designed to facilitate the educational goals of the dominant culture.

She then stated,

The structure and funding of public education leads me to believe that not everyone is dissatisfied with the status quo. Public schools generally reflect the neighborhood in which they are located. Good schools are found in rich neighborhoods and inferior schools are found in poor neighborhoods. Caucasians are more likely to be living in wealthy 
neighborhoods and they score higher on standardized tests. This isn't a secret. If our society was truly upset with the state of our children's education, we would do something.

Nancy's critique of educational inequality was not unique among students' oral comments and writing. She identified as a White woman who wanted to teach in diverse schools but needed answers about how to change unequal outcomes. She did not appreciate the authors' presumed goal of making her feel guilty for being privileged. Nancy was determined to use her privileged social and economic position to help others with fewer opportunities. Toward the end of the quarter, she shared that she grew up in a poor community in Oregon where the schools did not offer advanced placement courses or the basic courses needed to apply to the state university. This was not surprising to her peers since many had grown up in poor or working class White communities and shared this in the discussions.

By mid-quarter, it was obvious that our students did not reflect the imagined pre-service teachers for whom the texts were written. They recognized and appreciated diversity and wanted to learn how to teach students who were not experiencing academic success in nearby schools. Since many of our students have linguistically and culturally diverse backgrounds and are primarily non-White, they have personally addressed many of the challenges cited in books regarding culture. In his written response, one student stated,

Many years ago, I came to terms with the fact that I was a part of two cultures and could identify with both. Going back to biculturalism, I learned to realize that each culture had great and powerful aspects about them, as well as negative issues that still need to be dealt with. And because I can identify with both cultures, I can be both accepting and critical of them.

Like this student, many were aware of their culture because it differed from the K12 school culture, and they did not feel the need to read this in the textbooks.

Toward the end of the quarter, we read chapter 5 "Critical Pedagogy, Empowerment and Learning" in Nieto's (1999) book, which prompted Janice, a White veteran teacher, to provide several critiques and insights about the realities of teaching at her school. She wrote,

In [district], we still have some teachers (not many, but they still hang in there) who do not hold the same expectations for our students as the state does. They bemoan the family situations from which our students come and assert that "our kids just can't be at the same level." I have heard this spoken by Hispanic teachers as well as White teachers who consider the family situations to be so detrimental and damaging that the kids just "can't" overcome it. I think this kind of pity/compassion is a sure recipe for student failure.

She goes on to discuss racism as it related to her school: 
Perhaps it is more difficult to be racist in a school like mine where $95 \%$ of the students and staff are Hispanic. It would be so obvious and absurd if the teacher rarely called on a Hispanic student, instead favored the single African American child or Cambodian child in the class. Perhaps this is a bigger problem in middle class White neighborhood schools where the racially/ethnically different student is ignored. Also, perhaps my failure to perceive racism and bias in the teachers and curriculum may be related to the population we serve.

Janice did not oppose the texts and was quick to reflect on her social position and privilege as an individual and educator. After reading about the culture of power (Delpit, 1988), Janice wrote in a weekly paper,

Not only have I been part of the culture of power, I have used it to mentally judge others based upon their access to this group--those who can use the English language to communicate fairly effectively. I have continually benefited, at least socially/educationally, from my cultural capital when it comes to literacy.

Students were introduced to terms, theorists, and theories such as the culture of power and cultural capital (Bourdieu, 1986) through readings and lectures and used these to make sense of their experiences and how they planned to teach.

During the final week of the quarter, a group of students led an activity to demonstrate how it might feel to be deaf or hard of hearing. They wrote instructions in Spanish and asked the class to divide itself into two groups: fluent and non-fluent Spanish speakers. Janice chose the fluent Spanish group. Presenters were pleased when the class divided nearly equally with Spanish speakers being slightly larger. While this brought some embarrassment to a few students who admitted they should speak Spanish due to their cultural and ethnic background, no one expressed surprise at the linguistic diversity among us, which did not align with cultural/ethnic background.

Over the next two years, students' opposition to Nieto's (1999) book grew. While many identified with Nieto's discussion of her experiences growing up in a working-class, poor, non-White community, they did not feel a connection with the White teachers coming to terms with their privilege or with the emphasis on Puerto Rican and African American students because they did not represent the K-12 students and teaching population on the West Coast. Students wrote and spoke overwhelmingly positively about the final chapters in which Nieto emphasizes the importance of relationships and provides in her own words, "principal themes that have emerged throughout the book that have implications for student learning and teacher transformation" (p. 163) and conditions for improving student learning as part of comprehensive school reform efforts. Students wanted less time reading about the benefits of valuing diversity and more examples and suggestions on how to effectively teach a diverse student population. When invited to critique the readings, students suggested other books more applicable to our K-12 student population, pre-service teachers, and challenges in the greater Los Angeles area. I agreed and began using Banks' An 
Introduction to Multicultural Education (2008) as our core text, plus articles and chapters by Anyon (1980), Cochran-Smith (2001), Delpit (1988), Freire (1970), Kohl (2002), and Ladson-Billings (2002). I used media to prompt conversations and address key concepts and theories; however, the responses were not what I anticipated.

\section{The Absence of Media Shock Value}

With the increasing role of multimedia in students' lives and the possibilities this offers for teaching, I included movies and references to movies related to education. I showed the beginning of The Jerk, a 1979 comedy starring Steve Martin, which begins, "It was never easy for me. I was born a poor Black child. I remember the days, sittin' on the porch with my family, singin' and dancin' down in Mississippi" to make the point that race is socially constructed. Martin, a White comedian, is shocked when his mother tells him he is not Black. Later, Martin is working as a gas station attendant when three men in a low-rider car, smoking marijuana, attempt to steal gas, tires, and money and charge it to a credit card selected from one of many stolen purses in the backseat. The stereotypes are extreme. Several students were amused, not by the extreme caricatures and mockery of racism, but because, as one student explained through laughter about the gas station scene, "I know cholos like that from my neighborhood!" Students clearly understood media's perpetuation of stereotypes and racism but did not allow it to define them as individuals or members of particular groups while recognizing both subtle and blatant forms of racism.

The following year, I showed Smoke Signals (1998), a Sundance award winning film, to discuss a chapter in Spring's (1999) book about folk history and official history. The movie details life on a Coeur d'Alene Indian reservation and brilliantly juxtaposes their folk history, defined as oral history within families and communities which "can sometimes be a corrective to neglect or distortion of an identity found in official history" (p. 95), and official history, the history presented in textbooks, museums, and historical societies which gives a public demonstration of the people it discusses or "the product of decisions by publishers, authors, and public officials" (p. 97). During our conversation, a few students expressed disgust with the emphasis on alcoholism, boredom, hopelessness, and frustration on the reservation. One student, Joseph, grew up on a reservation in Arizona and validated the portrayal. He offered insights from his experiences but brought the focus back to education and the reasons for Native Americans' struggle with high rates of drop out, unemployment, and alcoholism. Without Joseph's insights and commitment to improving education for students of color, specifically Native American and Latino, the discussion may have remained narrowly focused on media and stereotypes without considering the serious implications for educational outcomes for those portrayed in the movie. 
The final example of media comes from a conversation with a student who mentioned that her brother was one of the Freedom Writers, a group of African American and Latino/a high school students labeled "at-risk" in Long Beach, California. The movie, Freedom Writers (2007), had recently been released and received a great deal of attention. I asked Lourdes if she saw the movie; she said she had not. Based on reviews and conversations with people who had seen the movie, she shared her aversion for the way the communities were portrayed as violent, poor, and destitute. She also shared how her mom worked hard to provide a safe, loving environment, and while the neighborhood did struggle with gang violence she felt the movie was extreme. She critiqued her brother's teacher but brought the conversation back to what the experience had offered her brother. Lourdes felt that Gruwell, the teacher who created the Freedom Writers, had a positive impact on her brother's life and despite the exaggerated negative portrayal of Lourdes' community, which she excused as necessary for a Hollywood movie, she was thankful for her brother's experience.

Using media to prompt conversations about racism, stereotypes, and forms of history can be effective. As with any text, students draw on their background knowledge and experiences to make sense of the messages. Students were not shocked by the portrayals of individuals closely related to them. Rather than focusing on stereotypes, critiques of history, or urban schools, the students moved conversations beyond these to focus on education and the impacts of these stereotypes on the students portrayed. The shock value of Hollywood did not impact them as I anticipated; rather, students were more concerned with how to change the educational opportunities for students with similar backgrounds to those in the movies. They wanted to discuss diversity in terms of opportunities from historical and current perspectives.

\section{Theories and Theorists: Making Sense of Their Own Education}

By the second year of teaching the course, I shifted from having students define culture, racism, and stereotypes to teaching and discussing theories such as critical pedagogy (Freire, 1970), hegemony (Gramsci, 1971), and social reproduction (Bourdieu, 1986). Students were hungry for new theories and conversations to increase their pedagogical knowledge. In fact, one student declared that she was tired of talking about multiculturalism and needed to know how to help her fourth graders read and write. I reminded her that teaching from a multicultural perspective, in addition to increasing her content knowledge, would serve her students well, to which she agreed. To address her and her peers' concerns, I increased the readings focused on pedagogy and academic achievement within historical and cultural contexts.

While still using Banks' book as the core text, I introduced students to the first two chapters of Freire's (1970) Pedagogy of the Oppressed. Many students found hope in critical pedagogy, contrasting it with their education and wanting to 
learn more about Freire and critical pedagogy. Patricia, who received her K-12 and undergraduate education in Mexico, wrote,

Critical pedagogy does not prepare students to live in an unjust society but to challenge it. Kids are valuable independent thinkers, with personal opinions, and facts that support their judgments. When a critical perspective is used students can explore and reflect about certain conditions in their lives and design strategies to change them.

She understood the challenges of living as a Mexican immigrant in a country where racism still exists and attending a program that did not recognize her Universidad Nacional Autónoma de México undergraduate degree as valid. Her attention remained fixed on how to maximize her future students' academic achievement and opportunities through critical pedagogy.

Patricia and her peers were upset when they realized they had not learned discourse to analyze their education. After reading Nieto and Freire, Fernando wrote,

After reading Freire, finally, I can put my finger on why my educational experiences differ so dramatically. My K-12 education was by far a reflection of "banking education"... teachers considered the best students as those who could regurgitate the most information without questioning or developing any consciousness about the material. Also, these same teachers considered the worst students as those who questioned or developed a consciousness about the relevance of the content material or pedagogy... The information I learned did not inspire, empower, and propose to liberate, nor did it "humanize" me. I now realize that such educational conditioning helps perpetuate dominance and reinforces the status quo. My K-12 education was devoid of critical reflection, obtaining a personal consciousness, and thus any path that would lead to action.

Fernando and his classmates discussed empowerment, reading the world and reading the word, and the anger they felt at not learning to effectively "read the word" (Freire, 1970). Many expressed resentment toward former teachers who did not challenge them academically. They believed that the best form of empowering students was to maintain academic excellence and high expectations in the classroom, which meant a high level of pedagogical content knowledge on their part. They recognized that their own expertise in the content areas and pedagogy is critical to their future students' success. The pre-service teachers understood that they needed to personally strive for excellence within their own education so their $\mathrm{K}-12$ students would have more opportunities, such as access to higher tracked programs and classes and a realistic chance at being accepted at a university or passing the California high school exit exam.

Students were equally passionate about understanding hegemony, cultural capital, and social reproduction because they recognized how these theories explained their educational experiences. With many of our students coming straight from undergraduate programs to the credential program, it is important to note that $40 \%$ of our incoming freshmen are the first in their family to 
attend college (conversation with Director of University Enrollment Services, 2007). Therefore, many students recognize the difficulty of disrupting social reproduction and their responsibility to ensure that K-12 students gain institutional capital to maximize their opportunities. As Fernando mentioned, students could not "put their finger on" or discuss their educational experiences without the theory and sociological discourse of education. Although some found the readings to be challenging, such as a chapter by Bourdieu (1986), they wanted to understand the social structures that perpetuated inequality in education and their role in disrupting cycles, all of which are theories and concepts closely related to diversity.

\section{Revising Core Projects to Meet Expected Outcomes}

Since 2002, students had to complete two cross-cultural projects. These included: (1) a visit to a cultural museum with a research paper including a historical overview of the culture featured at the museum and (2) a multimedia cultural presentation by groups of students that "promotes and validates crosscultural awareness, understanding and appreciation" and focuses on the historical and social development of a specific cultural/ethnic group through cultural artifacts (e.g., music, fine arts, sculpture, dance, and architecture).

\section{Cultural Museum}

Students had to visit a museum focused on a cultural group, then write about the culture and museum. Many selected the Museum of Tolerance, which aims to inform visitors about intolerance around the world with a strong emphasis on the Holocaust (www.museumoftolerance.com). Therefore, students who visited this museum wrote about the Jewish experience, but few students will teach in schools with a significant Jewish population. Others visited art museums, such as the Asian art museum, which features art from many different countries and lacks a specific focus on any one cultural group. Perhaps furthest removed from the focus on K-12 students' cultures in local schools were visits to museums such as the Bowers Museum and Autry National Center, which yielded research papers on Egyptians, Chumash Indians, and African American cowboys. Students agreed they were unlikely to have students in their classes that reflected these groups.

\section{Cultural Presentation}

The second project was intended to teach about the cultural practices of students they may have in their future classrooms. In a 30-45 minute 
presentation, students were expected to link a cultural group's historical and social development to education. Students appropriately pointed out that the projects essentialized the focal group's cultural practices and offered oversimplified notions about the group's educational and social experiences. Many students were uncomfortable presenting on the cultural practices of students that were in the class because they did not want to perpetuate stereotypes.

A related critique about the textbooks and the cultural presentation was the way certain books clustered a cultural group into one chapter such as African Americans, Asians, or Hispanics/Latinos, and so on. Students belonging to these broadly defined groups pointed out differences between groups such as Vietnamese and Chinese who were often clumped into one category. Some students pointed out the within-group differences as being more extreme than between-group differences due to class and generation. Students were accurate in identifying the hypocrisy of having cultural group presentations, which generalized a cultural group into a few dozen PowerPoint slides and a discussion of their history, holidays, artistic contributions, clothing, and foods.

Often, student-led discussions were more enlightening than the presentations. A historical and political discussion about the differences between the terms "Chicano/Xicano," "Latino," and "Hispanic" evolved from a discussion about language programs and how people are judged by their proximity to the Spanish language. This discussion was led by a student working with high school students as an admissions counselor and recruiter for state colleges. Several students were teaching in high needs areas (i.e., high school science and math and special education) and validated or refuted readings based on what they experienced in classrooms. After reading about "the Catholic school effect" in Nieto's (1999) book, which states that "African American students who have been described as most 'at risk' - the most economically disadvantaged students and those who start with the worst academic records-have had the highest rate of achievement in Catholic school" (p. 17), Raul shared his experience in Catholic school from K-8 compared to his education in a public high school and was appalled by the public school experience. He described teachers as easy and light on discipline and the curriculum as less rigorous. His two elementaryaged children were in Catholic school because his concern was about academic achievement. He and his spouse took responsibility for teaching their children about their culture, rather than depending on a teacher or the school. Other students felt more academically prepared by Catholic school in which Nieto (1999) states, "generally the pedagogy and curriculum of Catholic schools can be characterized as traditional and Eurocentric" (p. 17). This was another example of students' skepticism toward multicultural education if the focus did not simultaneously address high academic achievement.

After sitting through dozens of cultural presentations and reading research papers, I realized that the students were the curriculum and a great deal of knowledge resided within our four walls. The projects needed to be redesigned to focus on the K-12 population in our neighboring districts and what our students 
needed to know to become effective pedagogues with a focus on social justice and continued appreciation for diversity.

\section{Refining the Course}

When students are already aware of and sensitive to educational inequalities and diversity, we serve our students' needs best by moving away from texts that oversimplify diversity and assume that pre-service teachers are White and middle class. For our students, assignments and texts that focus on intersections of diversity and K-12 student achievement are far more meaningful. During my first quarter of teaching, one student wrote:

Ultimately, school reform needs to create a socially just environment that empowers our students. In order to achieve this, we as teachers need to use a critical lens and turn it around to view ourselves. We need to be aware of our own personal identities, confront our own biases, recognize social inequalities in our institutions and be willing to fight for changes. We must transform ourselves into successful educators based on these findings and actions and create a place where all students can equally receive a high-end education.

This student substituted in bilingual programs and was appalled by the lack of resources and overwhelming evidence of social reproduction. His concerns about how to change the learning opportunities of Latino English learners were pressing since as a group they have one of the highest dropout rates and lowest test scores in the state. They are also overrepresented in overcrowded urban schools (UCLA/IDEA \& UCACCORD, 2007). His concern about seeing diversity in high school graduating classes and college undergraduate courses is closely linked to his own knowledge as a pre-service teacher.

Since many of our students are the "others" or more similar to K-12 students referenced in teacher education textbooks, our institution and perhaps ones similar to ours may serve students best by focusing on the relationship between diversity and academic outcomes and opportunities for K-12 students. Our students are desperate to learn how to effectively teach literacy and mathematics in diverse learning contexts because our non-White $\mathrm{K}-12$ students continue to do poorly (UCLA/IDEA \& UCACCORD, 2007). Our students also believe that culture is being taught in the home and community, and they have little patience for the assumption that this is not happening. Tracie, a White female whose grandparents were poor immigrants but made sure their family knew their culture, stated, "Teachers cannot be expected to teach everything, there must be some things that parents need to pass on to their children... or the students might as well become live-in residents of the school and I might as well just become their parent!" She understood her role as the educator of content within a diverse learning environment, not as the primary teacher of her students' cultures. 
As the course coordinator, I eliminated the cultural presentation and cultural museum research paper. Instead, students conduct ethnographic research projects on local schools, districts, and surrounding communities. They collect and analyze data. They research changes in demographics over the past 25 years, how this impacts pedagogy and policy, and how this directly impacts students. The research project teaches students how to collect quantitative and qualitative data, to inquire and reflect on findings, and to move toward answers for the benefit of their diverse K-12 students. Essentially, students are learning to become researchers, to engage in action research in their future classrooms and tailor their instruction based on data rather than hunches and suspicions. For the past two quarters, the final ethnographic case study project has averaged 50 60 pages of analysis, supporting documents, and a multimedia component.

The readings have also changed. Students continue to read Banks (2007), and The California Educational Opportunity Report (UCLA/IDEA \& UCACCORD, 2007), Status of the Teaching Profession (The Center for the Future of Teaching \& Learning, 2005), articles about the California high school exit exam, and the Report from The Center for the Future of Teaching and Learning about Special Education (The Center for the Future of Teaching \& Learning, 2004). They continue to read articles by Delpit (1988), Anyon (1980), and Sleeter (2001). The course is no longer focused on convincing students that culture and diversity are important, but on preparing students with a foundational knowledge of education to disrupt social reproduction and increase their future students' opportunities and academic achievement. Without understanding the current state of education, students will not understand the seriousness of achievement gaps and what is occurring in many K-12 California classrooms, particularly those serving historically marginalized populations.

\section{Conclusion}

Our students do not reflect the "average" American teacher as much as our increasingly diverse national K-12 student population. Few are disillusioned about diversity and the importance of culture. As Tracie suggested, students are likely to learn about their culture in their homes and communities. Certainly we appreciate and celebrate students' cultures, but an important way to show respect and care for students and their families is to teach the content with a sensitivity and respect toward diversity and students' needs and trust family and community members to teach students how to exist as men, women, and citizens within their respective communities and beyond.

Granted, we should not assume that all students recognize the importance of culture and its impacts on students' learning simply because they have lived in diverse communities and attended diverse schools. However, by reminding students of the importance of diversity while focusing their attention on data that show achievement gaps based on race/ethnicity, socioeconomics, and linguistic background, even the most skeptical or biased student is challenged to grapple 
with these inequalities. When pre-service teachers do not reflect the teachers portrayed in many multicultural education textbooks, we need to reassess the purpose and focus of the course. Our students have one year to prepare to become effective educators, and we cannot waste time on outdated teaching practices and curriculum. Just as our K-12 student population is rapidly changing, so too is the pre-service teaching population at our institution and perhaps other institutions. Therefore, we must prepare them with the tools and knowledge to disrupt the cycles of educational inequality that many of them faced as K-12 students.

\section{References}

Alexie, S. (Producer), \& Eyre, C. (Director). (1998). Smoke signals [Motion picture], USA: ShadowCatcher Entertainment.

Anyon, J. (1980). Social class and the hidden curriculum of work. Journal of Education, 162(1), 67-92.

Banks, J. A. (2008). An introduction to multicultural education. ( $4^{\text {th }}$ ed.). Boston: Pearson.

Bennett, C. I. (2003). Comprehensive multicultural education: Theory and practice ( $5^{\text {th }}$ ed.). Boston: Allyn and Bacon.

Bourdieu, P. (1986). Forms of capital. In Handbook of theory and research for the Sociology of Education (pp. 241-258). New York: Greenwood.

California State University Statistical Reports (2007). Retrieved December 1, 2009 from http://www.calstate.edu/AS/stat abstract/stat0708/index.shtml

Cochran-Smith, M. (2001). Learning to teach against the (new) grain. Journal of Teacher Education, 52(1), 3-4.

Crawford, J. (2004). Educating English learners: Language diversity in the classroom. Los Angeles: Bilingual Educational Services.

Delpit, L. (1988). The silenced dialogue: Power and pedagogy in educating other people's children. Harvard Educational Review, 58(3), 280-298.

Ed-Data, District Profile, Los Angeles Unified School District (2008-2009). Retrieved December 1, 2009 from http://www.eddata.k12.ca.us/

Ed-Data, State of California Education Profile (2008 - 2009). Retrieved December 1, 2009 from http://www.ed-data.k12.ca.us/Navigation/ fsTwoPanel.asp?bottom=\%2Fprofile.asp\%3Flevel\%3D06\%26reportNumb er\%3D16

EdSource (2006). California high school exit exam gets real: Implications for the class of 2006 and beyond. Mountain View, CA: EdSource Report.

Freire, P. (1970). Pedagogy of the oppressed. New York: Continuum. 
Gollnick, D. M., \& Chinn, P. C. (2002). Multicultural education in a pluralistic society. Columbus, $\mathrm{OH}$ : Merrill Publishing Co.

Gramsci, A. (1971). Selections from the prison notebooks. Geneva, Switzerland: International Publishers.

Grant, C., \& Sleeter, C. (2007). Doing multicultural education for achievement and equity. New York: Routledge.

Jennings, T. (2007). Addressing diversity in U.S. teacher preparation programs: A survey of elementary and secondary programs' priorities and challenges from across the United States of America. Teaching and Teacher Education, 23(8), 1258-1271.

Kohl, H. (2002). Topsy-turvies: Teacher talk and student talk. In L. Delpit and J. Kilgour Dowdy (Eds.) The skin that we speak: Thoughts on language and culture in the classroom (pp. 145-161). New York: New Press.

Ladson-Billings, G. (2002). I ain't writin'nuttin': Permission to fail and demands to succeed in urban classrooms. In L. Delpit and J. Kilgour Dowdy (Eds.) The skin that we speak: Thoughts on language and culture in the classroom (pp. 107-120). New York: New Press.

Levine, D. (producer), (2007). Freedom writers [Motion picture]. USA: Paramount Pictures.

National Center for Educational Statistics (2009). "Condition of Education, 2009". U.S. Department of Education. Retrieved December 1, 2009 from http://nces.ed.gov/programs/coe/2009/section1/table-1er-1.asp

Nieto, S. (1999). The light in their eyes: Creating multicultural learning communities. New York: Teachers College Press.

Noel, J. (2000). Developing multicultural educators. Boston: Allyn \& Bacon.

Ovando, C. J., Combs, M. C., \& Collier, V. P. (2002). Bilingual and ESL classrooms: Teaching in multicultural contexts. Boston: McGraw-Hill.

Pewewardy, C. (2005). Shared journaling: A methodology for engaging white pre-service students into multicultural education discourse. Teacher Education Quarterly, 32(1), 41-60.

Reiner, C. (Producer), (1979). The Jerk [Motion picture]. USA: Aspen Film Society.

Sims, C. (2010). Increasing the minority CTE teacher pipeline. Techniques: Connecting Education and Careers, 85(1), 26-29.

Sleeter, C. (2001). Preparing teachers for culturally diverse schools: Research and the overwhelming presence of Whiteness. Journal of Teacher Education, 52(94), 94-106.

Sprangenberg-Urbaschat, K., \& Pritchard, R. (1994). Kids come in all languages. Newark, DE: International Reading Association. 
Spring, J. (1999). The intersection of cultures: Multicultural education in the United States and the global economy. Boston: McGraw Hill.

State of California Education Profile (2006-2007). Retrieved December 1, 2009 from http://www.ed-data.k12.ca.us/welcome.asp

The Center for the Future of Teaching \& Learning (2004). Special education: Not so special for some - qualified teachers in short supply for special education students. Berkeley, CA: The Center for the Future of Teaching \& Learning.

The Center for the Future of Teaching \& Learning (2005). Status of the teaching profession. California State University, Office of the Chancellor: Policy Analysis for California Education. Berkeley, CA: Center for the Future of Teaching and Learning.

UCLA/IDEA \& UCACCORD (2007). California educational opportunity report. University of California Los Angeles Institute for Democracy, Education and Access and University of California All Campus Consortium on Research for Diversity. Los Angeles: University of California Los Angeles.

U.S. Census Bureau (2009). Population estimates. Retrieved December 1, 2009 from http://www.census.gov/popest/states/NST-ann-est.html

Wiseman, D., Knight, S., \& Cooner, D. (2005). Becoming a teacher in a fieldbased setting. Belmont, CA: Thompson and Wadsworth Publishers. 